\title{
Autochthonous infection of buffaloes and cattle by Fasciola hepatica in Minas Gerais, Brazil
}

\author{
Infecção autóctone de búfalos e bovinos por Fasciola hepatica em Minas Gerais, Brasil \\ Ruth Massote Dracz; ${ }^{1}$ Walter dos Santos Lima ${ }^{1}$
}

\begin{abstract}
${ }^{1}$ Laboratório de Helmintologia Veterinária, Departamento de Parasitologia, Instituto de Ciências Biológicas, Universidade Federal de Minas Gerais - UFMG, Belo Horizonte, MG, Brasil
\end{abstract}

Received May 6, 2014

Accepted June 25, 2014

\begin{abstract}
Fasciola hepatica is a digenetic trematode that parasitizes the bile ducts of different species of vertebrate hosts. In Brazil, this parasitosis is expanding and occurrences have been reported in the southern, southeastern, central-western and northeastern regions. This study aimed to report the first case of naturally infection of buffaloes by this parasite in the state of Minas Gerais. A total of 250 stool samples, 176 from cattle and 74 from buffaloes, from the districts of São José da Lapa and Pedro Leopoldo, were examined. Also, 402 snails of the genus Lymnaea were collected on the same farms and the viability of the eggs from naturally infected buffaloes and cattle and the susceptibility of the snails to infection were tested. A total of 54 animals were found to be positive, 33 cattle (18.75\%) and 21 buffaloes (28.37\%), and two molluscs showed immature forms of $F$. hepatica. In experimental infection of specimens of Lymnaea, cercariae were obtained through spontaneous elimination from the $57^{\text {th }}$ day post-infection onwards. The importance of this first case report can be emphasized because it confirms that this parasite is being dispersed in municipalities in this state that had previously been considered to be unaffected.
\end{abstract}

Keywords: Fasciola hepatica, buffaloes, epidemiology, cattle.

\section{Resumo}

Fasciola hepatica é um trematódeo digenético que parasita os ductos hepáticos de diferentes espécies de hospedeiros vertebrados. No Brasil, essa parasitose encontra-se em expansão e a sua ocorrência tem sido descrita nas regiōes Sul, Sudeste, Centro-oeste e Nordeste. Esse trabalho objetivou relatar o primeiro caso de búfalos naturalmente infectados no estado de Minas Gerais. Um total de 250 amostras de fezes, sendo 176 de bovinos e 74 de búfalos, provenientes dos municípios de São José da Lapa e Pedro Leopoldo foram examinadas. Também foram coletados 402 moluscos do gênero Lymnaea nas propriedades estudadas e a viabilidade dos ovos oriundos dos búfalos e bovinos naturalmente infectados e a susceptibilidade do molusco a infecçáo foi testada. Um total de 54 animais apresentavam-se positivos sendo 33 bovinos $(18,75 \%)$ e 21 bubalinos $(28,37 \%)$ e dois moluscos apresentaram formas imaturas de $F$. hepatica. $\mathrm{Na}$ infecção experimental dos exemplares de Lymanea, foram obtidas cercarias eliminadas espontaneamente a partir do $57^{\circ}$ dia pós infecção. Ressalta-se a importância desse primeiro relato de caso, pois certifica a dispersão do parasito em municípios antes considerados indenes no Estado.

Palavras-chave: Fasciola hepatica, búfalos, epidemiologia, gado.

\section{Introduction}

Fasciola hepatica (Linnaeus, 1758) is a digenetic trematode of the family Fasciolidae that shows cosmopolitan distribution and parasitizes the hepatic ducts of different species of vertebrate hosts. In Brazil, occurrences of this parasite have been reported in the southern, southeastern, central-western and northeastern regions, parasitizing cattle, sheep, buffaloes and wild animals such as coypus and capybaras (SILVA SANTOS et al., 1992; CUNHA et al., 2007;

\footnotetext{
${ }^{*}$ Corresponding author: Walter dos Santos Lima

Universidade Federal de Minas Gerais - UFMG, Av. Presidente Antônio

Carlos, 6627, CEP 31270-901, Belo Horizonte, MG, Brasil

e-mail: wlima@icb.ufmg.br
}

BELLATO et al., 2009; LIMA et al., 2009; CARNEIRO et al., 2010; BENNEMA et al., 2014). Human cases have also been reported in the southern, central-western, southeastern, northeastern and northern regions, with the largest number of cases in the southern and southeastern regions respectively (MAS-COMA et al., 1999; PILE et al., 2000; OLIVEIRA et al., 2007).

Fasciolosis can cause major economic losses in parasitized herds because of reduced productivity of milk and meat, growth retardation in young animals, rejection of livers in slaughterhouses, abortions, mortality and expenditure on controlling this parasitosis (LIMA et al., 2009). 
The increasing geographical dispersion of Fasciola hepatica in Brazil is due to trade and transfer of parasitized animals from areas where the disease is enzootic to locations that are unaffected but have favorable epidemiological conditions. Among these favorable conditions is the presence of snails of the genus Lymnaea, which are intermediate hosts for $F$. hepatica. Thus, such conditions also include the climatic and environmental factors that provide a suitable habitat for these snails, such as high humidity and adequate temperature and rainfall (LIMA et al., 2009; ALVES et al., 2011; MARTINS et al., 2012).

This study aimed to report on the spread of the parasite in the state of Minas Gerais and also provides the first report of naturally infected buffaloes in regions that had been considered to be unaffected.

\section{Methods}

\section{Area of study}

This study was conducted in the municipalities of São José da Lapa (latitude 19 $70^{\circ}$ 57.2" south; longitude 43 97' 47.6" west) and Pedro Leopoldo (19 $37^{\prime} 12^{\prime \prime}$ south; $44^{\circ} 2^{\prime} 38^{\prime \prime}$ west), which are in the middle metropolitan region of Belo Horizonte, state of Minas Gerais, Brazil. These municipalities are lie within the basin of the Velhas river, and some of its tributaries, such as Córrego do Carranca, Ribeirão das Neves and Ribeirão da Mata, pass through several farms in the region, thus offering favorable epidemiological conditions for maintenance of the cycle of Fasciola hepatica.

Furthermore, the study area had a history of seven locally-reared adult buffaloes from which, after slaughtering, the livers were condemned due to infection by this parasite. Based on these data, fecal samples were collected from animals on the farm concerned and from neighboring farms, to search for other cases of infection.

\section{Parasitological examinations of cattle and buffaloes}

Nine farms drained by the streams Córrego do Carranca and Ribeirão da Mata were selected. On these farms, stool samples were collected directly from the rectum of each animal over the age of 12 months. The samples were collected in properly labeled plastic bags, packed in an insulated box and transported to the Veterinary Helminthology Laboratory, Federal University of Minas Gerais, where they were processed in accordance with the technique of Girão and Ueno (1982) in order to quantitatively and qualitatively diagnose $F$. hepatica eggs.

\section{Molluscs}

Searches for snails of the genus Lymnaea, an intermediate host for $F$. hepatica, were also conducted on these farms, on the banks of Córrego do Carranca and Ribeirão da Mata and on aquatic plants in these streams. Water tanks and drinking troughs used by the animals were also inspected when present. The specimens found were transported to the laboratory and dissected under a stereoscopic microscope to investigate the presence of larval stages of the parasite. Among the molluscs collected, ten of them were separated out and kept in the laboratory for breeding. These specimens were kept in plastic vats containing dechlorinated water and fed with lettuce.

Viability of eggs coming from naturally infected cattle and buffaloes and susceptibility of L. columella collected on the farms studied, to infection by Fasciola hepatica

To evaluate the viability of the eggs of $F$. hepatica eliminated by naturally infected cattle and buffaloes, eggs recovered from these hosts were kept in petri dishes in an oven at $27{ }^{\circ} \mathrm{C}$ for incubation. After 13 days, the dish containing the eggs was placed under a spotlight for 1 hour, for the miracidia to hatch. Fortyeight molluscs of size $5 \mathrm{~mm}$, which were obtained from the first generation of molluscs that had been collected on the farms, were used for this experimental infection. The specimens of Lymnaea were individually placed in the wells of a cell culture plate, each containing $2 \mathrm{ml}$ of dechlorinated water and two miracidia. The snails were kept on the plates for a period of 24 hours. They were then transferred to plastic vats under the same conditions as described above. Starting 50 days after infection, the walls and bottom of the vat were inspected daily under a microscope, to search for cercariae and metacercariae eliminated by the snails.

\section{Results and Discussion}

A total of 250 stool samples was collected: 176 from cattle and 74 from buffaloes. The fecal examination showed that a total of 54 animals were positive for Fasciola hepatica eggs: 33 cattle (18.75\% of the samples) and 21 buffaloes (28.37\% of the samples). The number of $F$. hepatica eggs eliminated in four grams of feces, shown through analysis using the technique of Girão and Ueno (1982), ranged in the cattle from 1 to 84 eggs and in the buffalo from 2 to 330 eggs. The percentage of positive animals also varied between the farms studied, as shown in Table 1.

Several similar studies have been conducted describing buffaloes that were naturally infected with $F$. hepatica. Pile et al. (2001) made the first report on this parasite in young and adult buffaloes in the municipality of Marica, state of Rio de Janeiro, with a positivity rate of $2.5 \%$ among the 120 samples analyzed.

The highest prevalence rates found were recorded by Marques and Scroferneker (2003) in a study conducted in the state of Rio Grande do Sul. In an analysis on slaughtered animals, they found a prevalence of $10.34 \%$ among 377 livers from cattle and $20 \%$ among 105 livers from buffaloes infected with $F$. hepatica. Carneiro et al. (2010) reported natural infection by $F$. hepatica in buffaloes for the first time in the south of the state of Espírito Santo, with a positivity rate of $46.67 \%$ among 15 samples. These authors also reported that infected cattle and sheep were present on the farm, along with L. columella, but no examination of infection in snails was performed. 
Table 1. Total number of fecal samples collected from cattle and buffalo on the farms studied, number of positive samples for Fasciola hepatica eggs and the percentage (\%) positivity in each farm.

\begin{tabular}{ccccc}
\hline Farm & Species studied & Total number of samples collected & Positive samples for $\boldsymbol{F}$. hepatica eggs & \% positive animals in each farm \\
\hline $\mathbf{1}$ & buffalo & 19 & 19 & $100 \%$ \\
$\mathbf{2}$ & buffalo & 26 & 1 & $3.84 \%$ \\
$\mathbf{3}$ & buffalo & 29 & 1 & $3.44 \%$ \\
$\mathbf{4}$ & bovine & 19 & 3 & $18.75 \%$ \\
$\mathbf{5}$ & bovine & 37 & 5 & $13.51 \%$ \\
$\mathbf{6}$ & bovine & 45 & 7 & $15.55 \%$ \\
$\mathbf{7}$ & bovine & 44 & 6 & $13.63 \%$ \\
$\mathbf{8}$ & bovine & 24 & 10 & $41.66 \%$ \\
$\mathbf{9}$ & bovine & 7 & 2 & $28.57 \%$ \\
\hline
\end{tabular}

Lima et al. (2009) studied occurrences of F. hepatica in cattle in 120 municipalities in the state of Minas Gerais, from which a total of 6.255 fecal samples and 492 molluscs Lymnaea were collected. Among the municipalities studied, 16 showed positive animals. Among the molluscs collected, four were found to be naturally infected with $F$. hepatica, thus demonstrating the spread of fasciolosis in this state. Their data corroborate the present paper.

Alves et al. (2011) reported on the distribution of and factors connected with Fasciola hepatica infection in cattle in southern Espírito Santo and analyzed 50 farms selected in ten municipalities of the state. These authors observed a frequency of fasciolosis of $21.33 \%$ and emphasized that the area studied presented great epidemiological importance due to its geographical position covering two significant hydrographic basins. The rivers of these basins flow through the states of Espírito Santo, Minas Gerais and Rio de Janeiro, thus allowing the disease to spread not only in Espírito Santo but also in other states.

Bennema et al. (2014) reported on occurrences of Fasciola hepatica in cattle in Brazil and observed that in Minas Gerais all the infected municipalities were located in the south of the state. Our results showed the presence of the parasite in the center-south region of the state, again confirming the expansion of fasciolosis.

In relation to the intermediate host of $F$. hepatica, snails of the genus Lymnaea were only found on five of the nine farms investigated in this study. A total of 402 specimens were collected, of which two had immature forms of the parasite $(0.5 \%)$. Other studies have been conducted to estimate the natural rate of infection of Lymnaea by F. hepatica, since the presence of the intermediate host in the environment is a fundamental factor in the epidemiology of fasciolosis. Coelho and Lima (2003) studied the natural infection rate of molluscs in the municipality of Itajubá, Minas Gerais, and found prevalences ranging from 0.9 to $5.2 \%$. Their rates were higher than what was found in the present study $(0.5 \%)$, but it is noteworthy that the work of Coelho and Lima (2003) was conducted in an area that is considered endemic for the parasite. Gomes et al. (2002) also examined naturally infected snails, and reported an infection rate of $5.22 \%$ among 134 specimens collected in the municipality of Goytacazes, in the state of Rio de Janeiro.

In our experimental infection of specimens of Lymnaea, cercariae of $F$. hepatica were found to be spontaneously eliminated from the $57^{\text {th }}$ day post-infection onwards, thus demonstrating the viability of the eggs and the susceptibility of these snails to infection. These data corroborate other authors' observations (BORAY, 1996;
SOUZA et al., 2002), with spontaneous elimination of cercariae at close to 60 days post-infection.

The high prevalence found in buffaloes in the present study was because the farms had ponds and flooded areas with which the buffaloes had constant direct contact and where Lymnaea molluscs were present. It is important to emphasize all these factors, as well as the presence of infected native vertebrate hosts and environmental conditions favorable towards maintaining the cycle, as also reported by several authors (COELHO; LIMA, 2003; LIMA et al., 2009). This first reported case of naturally infected indigenous buffaloes and cattle in the state of Minas Gerais, in areas previously considered to be free from infection stands out in importance because it shows that this parasite has become dispersed to municipalities in this state that previously were considered to be unaffected.

\section{Acknowledgments}

This research was supported by the Coordination of Improvement of Higher Education Personnel Support (CAPES), the National Council for Scientific and Technological Development (CNPq) and Pró-Reitoria de Pesquisa of Universidade Federal de Minas Gerais. WSL and RTF are supported by CNPq fellowships.

\section{References}

Alves DP, Carneiro MB, Martins IVF, Bernardo CC, Donatele DM, Pereira OS Jr, et al. Distribution and factors associated with Fasciola hepatica infection in cattle in the south of Espírito Santo State, Brazil. J Venom Anim Toxins incl Trop Dis 2011; 17(3): 271-276. http://dx.doi. org/10.1590/S1678-91992011000300006

Bellato V, Souza AP, Sartor AP, Haubold LP, Veiga N, Centenaro F. Ocorrência de Fasciola hepatica na população de capivaras (Hydrochaeris hydrochaeris) e em bovinos (Bos taurus) no município de Timbó, SC. Rev Cienc Agrovet 2009; 8(1): 66-70.

Bennema SC, Scholte RGC, Molento MB, Medeiros C, Carvalho OS. Fasciola hepatica in bovines in Brazil: data availability and spatial distribution. Rev Inst Med Trop São Paulo 2014; 56(1): 35-41. PMid:24553606. http://dx.doi.org/10.1590/S003646652014000100005

Boray JC. Studies on the relative susceptibility of some lymnaeids to infection with Fasciola hepatica and F. gigantica and on the adaptation of Fasciola spp. Ann Trop Med Parasitol 1996; 60(1): 114-124. 
Carneiro MB, Bernardo CC, Calais A Jr, Alves DP, Pereira OS Jr, Martins IVF. Fasciola hepatica em búfalos (Bubalus bubalis) no sul do Espírito Santo. Rev Bras Med Vet 2010; 32(2): 89-91.

Coelho LHL, Lima WS. Population dynamics of Lymnaea columella and its natural infection by Fasciola hepatica in the State of Minas Gerais, Brazil. J Helminthol 2003; 77(1): 7-10. PMid:12590657. http://dx.doi. org/10.1079/JOH2002138

Cunha FOV, Marques SMT, Mattos MJT. Prevalence of slaughter and liver condemnation due to Fasciola hepatica among sheep in the state of Rio Grande do Sul, Brazil 2000 and 2005. Parasitol Latinoam 2007; 62(3-4): 188-191.

Girão ES, Ueno H. Técnica de Quatro tamises para o diagnóstico coprológico quantitativo da fasciolose dos ruminantes. Pesq Agropec Bras 1982; 20(8): 905-912.

Gomes FF, Oliveira FCR, Pile EA, Lopes CWG. Estabelecimento de foco de fasciolose hepatica em propriedade do municipio de Campos dos Goytacazes no estado do Rio de Janeiro, Brasil. Rev Bras Parasitol Vet 2002; 11(2): 53-56.

Lima WS, Soares LRM, Barçante JMP, Barçante TA, Guimarães MP. Occurrence of Fasciola hepatica (LINNAEUS, 1758) infection in Brazilian cattle in the State of Minas Gerais. Rev Bras Parasitol Vet 2009; 18(2): 27-30. PMid:19500457. http://dx.doi.org/10.4322/ rbpv.01802006

Marques SMT, Scroferneker ML. Fasciola hepatica infection in cattle and buffaloes in the State of Rio Grande do Sul, Brazil. Parasitol Latinoam 2003; 58(3-4): 169-172.
Martins IVF, de Avelar BR, Pereira MJS, da Fonseca AH. Application of a geographical information system approach for risk analysis of fascioliasis in southern Espírito Santo State, Brazil. Geospat Health 2012; 6(3): 87-93.

Mas-Coma MS, Esteban JG, Bargues MD. Epidemiology of human fascioliasis: a review and proposed new classification. Bull World Health Organ 1999; 77(4): 340-346. PMid:10327713 PMCid:PMC2557647.

Oliveira AA, Nascimento AS, Santos TAM, Carmo GMI, Dimech CPN, Alves RMS, et al. Prevalence survey and factors associated with fascioliasis in the Municipality of Canutama, State of Amazon, Brazil. Epidemiol Serv Saúde 2007; 16(4): 251-259.

Pile E, Gazeta G, Santos JAA, Coelho B, Serra-Freire NM. Ocorrência de fascioliasis humana no município de Volta Redonda, RJ, Brasil. Rev Saúde Pública 2000; 34(4): 413-414. PMid:10973164. http://dx.doi. org/10.1590/S0034-89102000000400017

Pile E, Santos JAA, Pastorello T, Vasconcellos M. Fasciola hepatica em búfalos (Bubalus bubalis) no município de Maricá, Rio de Janeiro, Brasil. BrazJ Vet Res Anim Sci 2001; 38(1): 42-43. http://dx.doi.org/10.1590/ S1413-95962001000100008

Silva Santos IC, Scaini CJ, Rodrigues LAF. Myocastor coypus (Rodentia: Capromyidae) como reservatório silvestre de Fasciola hepatica (Lineu, 1758). Rev Bras Parasitol Vet 1992; 1(1): 27-30.

Souza CP, Magalhães KG, Passos LKJ, Santos GCP, Ribeiro F, Katz N. Aspects of the maintenance of the life cycle of Fasciola hepatica in Lymnaea columella in Minas Gerais, Brazil. Mem Inst Oswaldo Cruz 2002; 97(3): 407-410. PMid:12048573. http://dx.doi.org/10.1590/ S0074-02762002000300023 